\title{
Effect of defoliation intensity and timing on the growth of Populus alba and Salix babylonica x Salix alba
}

\author{
Efecto de la intensidad y el momento de la defoliación sobre el crecimiento de Populus alba \\ y Salix babylonica x Salix alba
}

\author{
Alejandra Rubio a , Verónica Loetti ${ }^{\text {a*}}$, Isabel Bellocq ${ }^{\text {a }}$ \\ *Autor de correspondencia: ${ }^{\text {a }}$ Universidad de Buenos Aires, Facultad de Ciencias Exactas y Naturales, \\ Buenos Aires, Argentina, vloetti@ege.fcen.uba.ar
}

\begin{abstract}
SUMMARY
Insect defoliations have detrimental impacts on timber production in commercial tree plantations. The effect of intensity and timing of defoliation on the growth of two commercial salicaceae was assessed at plantations located in the Delta of the Paraná River, Argentina. Experimental trees were randomly selected from two 1-year-old plantations of the most common clones planted in forestry production, Populus alba 'Villafranca' ("I-58/57") and Salix babylonica x Salix alba ("A-250/33"). We used a pre-post design to evaluate the effect of five intensities of manual defoliation (i.e. $100 \%, 75 \%, 50 \%, 25 \%$, and $0 \%$ as control) applied in four different times during the growing season (i.e. October, November, December and January) on tree height and diameter at breast height (DBH). Results indicated that manual defoliation negatively affected the growth of the studied poplar and willow clones in both height and diameter, and that the magnitude of the effect depended on the intensity and timing of defoliation. Willows were only affected by defoliation conducted during the spring (October and November); complete defoliation caused the highest reduction in growth (46 \% reduction in height and $62 \%$ in DBH compared to the control). Manual defoliation of poplars had a significant effect on growth at any time during the springsummer; trees subjected to $100 \%$ defoliation showed the highest growth reductions (up to $76 \%$ in height and $88 \%$ in DBH compared to control). This study indicated that commercial poplars were less tolerant to defoliation than willows.
\end{abstract}

Key words: Salicaceae, manual defoliation, tree growth, Delta of the Paraná River, Argentina.

\section{RESUMEN}

Las defoliaciones causadas por insectos tienen impactos perjudiciales sobre la producción de madera en plantaciones comerciales de árboles. El efecto de la intensidad de defoliación sobre el crecimiento en altura y diámetro de dos salicáceas de uso comercial fue evaluado en plantaciones del Delta del Río Paraná, Argentina. Los árboles experimentales fueron elegidos al azar de plantaciones de un año de edad de clones comúnmente utilizados en la producción forestal, Populus alba 'Villafranca' (“I-58/57") y Salix babylonica x Salix alba ("A-250/33“). Mediante un diseño antes-después fue evaluado el efecto de cinco intensidades de defoliación manual (100 \%, $75 \%, 50 \%, 25 \%$, y $0 \%$ como control) aplicadas en cuatro épocas de la estación de crecimiento (octubre, noviembre, diciembre y enero) sobre la altura y el diámetro a la altura del pecho (DAP) de los árboles. Según los resultados, la defoliación manual afectó negativamente el crecimiento de los clones estudiados, en diámetro y altura; la magnitud del efecto dependió de la intensidad y del momento de la defoliación. Salix sp. solo fue afectado por defoliaciones de primavera (octubre y noviembre); la defoliación completa causó las mayores reducciones en el crecimiento (46 \% en altura y 62 \% en DAP). La defoliación en Populus sp. afectó el crecimiento en cualquier momento de primavera-verano; los árboles completamente defoliados mostraron las mayores reducciones en el crecimiento (hasta $76 \%$ en altura y $88 \%$ en DAP). Este estudio indica que Populus sp. de uso comercial fue menos tolerante a la defoliación que Salix sp.

Palabras clave: Salicaceae, defoliación manual, crecimiento de los árboles, Delta del Río Paraná, Argentina.

\section{INTRODUCTION}

Insect defoliations have detrimental impacts on commercial tree plantations, mainly by reducing tree diameter and height growth. Many factors may influence the impact of herbivory on tree growth, such as the intensity and timing of defoliations, the photosynthetic activity of re- maining leaves and the nutrient storage capacity (Kulman 1971). Usually, light defoliations have either a negligible negative effect on tree health or an increase in the photosynthetic capacity (Trumble et al. 1993). In contrast, severe defoliations often cause growth reduction (Bassman et al. 1982, Reichenbacker et al. 1996, Powers et al. 2006), induce physiological changes affecting the susceptibility 
of trees to subsequent defoliations (Karban and Baldwin 1997) and increase mortality of trees subjected to repeated defoliations (Kulman 1971). Severe defoliations result in economic loss to commercial forestry plantations because it may lead to tree mortality and longer rotation periods (Cedervind 2003).

Commercial poplars (Populus spp.) and willows (Salix spp.) are planted in about 70 countries (Ball et al. 2005). They are not only used primarily for pulp and timber production, but also for non-wood products such as fodder, or for environmental purposes such as soil and water protection, windbreak, riparian buffering and phytoremediation; besides, they seem a promising alternative for bioenergy production (Dimitriou and Aronsson 2005, Marchand and Masse 2007). The global area planted with salicaceae was approximately 7 million ha in 2005 (Ball et al. 2005); of which near $2 \%$ was in Argentina (109,000 ha) and Chile (15,000 ha) (CIA 2004). Salicaceae are the third most important trees used for commercial plantations in Argentina (MAGP 2012), with a planted area of approximately 58,000 ha located within the Delta of the Paraná River, where poplars and willows are harvested 10-16 years after planting.

Many insect defoliators attack salicaceae plantations in the southern Cone. The most important generalist defoliators are ants of the genus Acromyrmex and a variety of lepidoptera larvae, such as Hylesia nigricans Berg, Macromphalia ancilla Philippi, Orgyia antiqua Linnaeus, and Ormiscodes cinnamomea Feisthamel. A few defoliators are specific to salicaceae, such as the lepidopterans Adetomeris erythrops Blanchard, and Euglyphis lignosa Walker, and the hymenopteran Nematus oligospilus Förster (Koch and Waterhouse 2000, Alderete et al. 2010). Nematus oligospilus was first detected in the Paraná River Delta in the mid-1980s and it has become a major pest in the region (Alderete et al. 2010) where it may be found in both willow and poplar plantations (Ede 2009).

The objective of this study was to evaluate experimentally the effect of defoliation intensity and defoliation timing on the growth in height and diameter of the poplar and willow species most commonly used for commercial plantations in Argentina. Trees were defoliated manually, simulating the defoliation pattern observed for $N$. oligospilus, which has emerged as a major pest of salicaceae in the southern Neotropics over the last decades. It was expected that defoliation would result in reduced growth compared with non-defoliated trees, and that the magnitude of the effect would depend on the level of defoliation. Additionally, it is expected that the effect of defoliation on growth varies depending on the time at which it occurs, as salicaceae trees have seasonal growth.

\section{METHODS}

Study site. The study was conducted in the private forest camp "Las Carabelas" ( $\left.34^{\circ} 10^{\prime} \mathrm{S}, 58^{\circ} 44^{\prime} \mathrm{W}\right)$ of Papel Prensa S.A., located in the Lower Delta of the Paraná Ri- ver, Buenos Aires province, Argentina. The Lower Delta is the terminal area of the Delta of the Paraná River, which is a freshwater wetland of remarkable environmental heterogeneity supporting high biological diversity (Kandus et al. 2006). The climate is temperate humid, with mean annual temperature between $16.7^{\circ} \mathrm{C}$ and $18{ }^{\circ} \mathrm{C}$ and annual precipitation of $1,000 \mathrm{~mm}$. The landscape is characterized by numerous pan-shaped islands with extended highlands bordering lowlands areas either temporarily flooded or permanently flooded and dominated by marshes. Originally, the highlands exhibited a complex forest physiognomy and high species richness; the marshes showed different species of bulrush, mainly Scirpus giganteus Kunth and Schoenoplectus californicus (C.A. Mey.) Soják. Currently, most of the original vegetation has disappeared as a result of human activities (Malvárez 1999, Kandus et al. 2006). Since mid-1990, the federal political economy has encouraged the development of forestry industry in the region, resulting in land conversion to willow and poplar plantations used primarily for pulp production (Kandus et al. 2006). Forestry activities in the area converted wetlands into dry land through dam constructions to protect plantations from periodic floods (Kandus and Minotti 2010).

Experimental design. The study was conducted in two 1-year-old stands with monocultures of the commercial clones most commonly used in the area: the poplar Populus alba 'Villafranca' ("I-58/57") and the willow Salix babylonica x Salix alba ("A-250/33"). The effect of defoliation intensity (treatment) and timing on the growth of both clones was evaluated using a pre-post design. For each clone, 200 trees were randomly selected and separated in four groups (50 trees each). Within each group, ten trees were subjected to one of five levels of manual defoliation: $100 \%, 75 \%, 50 \%, 25 \%$, and $0 \%$ (control). Treatments were applied once in each group of trees in a determined month randomly established from October to January. Pretest measures were taken at the time of the application of treatments; while the post-test measures of all trees treated were made in March.

Defoliation method. For each treatment level, the percentage of leaves to be removed was determined by visually dividing the tree crown into four quadrants, each of which contained about $25 \%$ of the foliage. Manual defoliation simulated the oviposition and herbivory spatial patterns of $N$. oligospilus (AWC 2006); i.e., from the crown base to the top of the tree (figure 1). The height and the diameter at breast height $(\mathrm{DBH})$ in each tree were measured using tape and caliper, respectively.

Data analyses. To evaluate the effect of defoliation on height and diameter growth of willows and poplars, a onefactor analysis of covariance (ANCOVA) was performed for each month, with defoliation intensity as the factor. Under similar environmental conditions, tree growth de- 


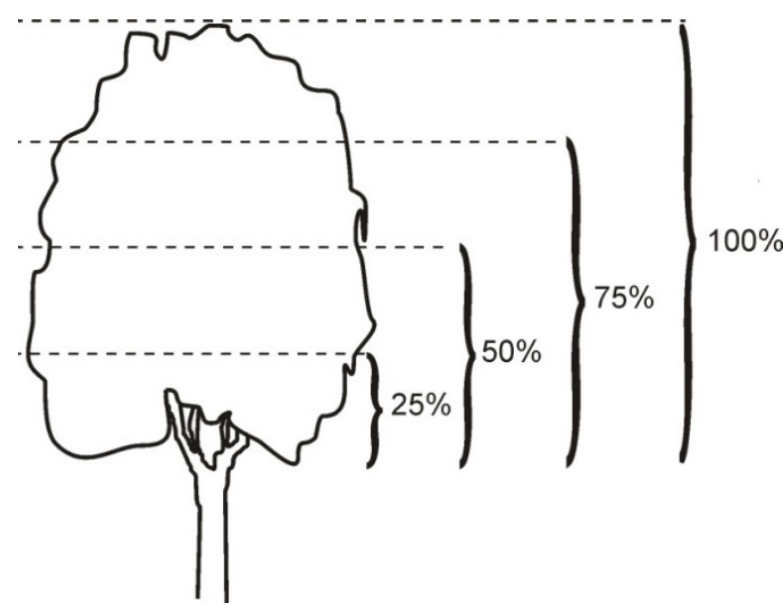

Figure 1. Pattern of manual defoliation used to assess the effects on willow and poplar growth. Defoliation simulated the bottomup pattern of oviposition and leaf consumption by Nematus oligospilus.

Patrón de defoliación manual usado para evaluar los efectos sobre el crecimiento de sauces y álamos. La defoliación desde la base hacia la copa del árbol simula el patrón de oviposición y de consumo de hojas de Nematus oligospilus.

pends on the initial size (younger plants have lower growth rate than that from older plants for a given time period), and the ANCOVA analyses allowed adjustment for initial differences in size. Final height and DBH were the dependent variables, while initial height and $\mathrm{DBH}$ were the co-variables. If the ANCOVA showed significant effects, Tukey's test was used to determine differences between treatment levels (Zar 1984). The statistical analysis was performed using the Statistica'99 Edition (StatSoft, Inc.).

To describe the growth pattern of trees, the mean difference between the initial and final values of total height and DBH (in absolute values) was estimated for each defoliation level. The effect of each defoliation level on tree growth was quantified as the percentage reduction in growth (\% RED G) of defoliated trees relative to control trees. Additional variables estimated for each defoliation level were the mean tree growth $(\mathrm{G})$ and the percentage growth relative to controls (\% G). For example, for trees with $25 \%$ defoliation, $G_{(25 \%)}=\Sigma$ (final height ${ }_{(25 \%)}-$ initial height $\left.{ }_{(25 \%)}\right) / 10, \% \mathrm{G}_{(25 \%)}=\left(\mathrm{G}_{(25 \%)} / \mathrm{G}_{(0 \%)}\right) \times 100$, and \% RED $G_{(25 \%)}=100-\% G_{(25 \%)}$. Positive values of \% RED G indicate growth reduction; while negative values indicate growth overcompensation (defoliated trees showing higher growth values than those shown by control trees).

\section{RESULTS}

Results of the ANCOVA indicated that the willow clone experienced a significant reduction in height and diameter growth when high defoliation levels occurred during the spring (October and November); no defoliation effects on growth were observed when the treatment was conducted during the summer (December and January) (figures 2A, 2B). The height of trees defoliated at $75 \%$ and $100 \%$ in November was significantly lower than that of control trees (ANCOVA: $\mathrm{F}_{4,44}=3.55, P<0.01$ ). Defoliations of $100 \%$ led to the highest percentage of growth reduction in height, up to $46.4 \%$; whereas defoliations of $50 \%$ in October induced overcompensatory growth (figure $2 \mathrm{~A}$ ). The DBH of trees subjected to defoliations of $75 \%$ and 100 $\%$ in October (ANCOVA: $\mathrm{F}_{4,44}=3.81, P<0.01$ ) and to defoliations of more than $25 \%$ in November (ANCOVA: $\left.F_{4,44}=5.11, P<0.01\right)$ was significantly lower than that of control trees (figure $2 \mathrm{~B}$ ). The highest growth reduction in diameter (62.3\%) was recorded in trees with $100 \%$ defoliation; while trees defoliated by $25 \%$ in January responded by overcompensation (figure 2B).

Manual defoliation had a significant effect on poplar growth during the entire growing season. The height of trees defoliated by $75 \%$ and $100 \%$ in October (ANCOVA: $\mathrm{F}_{4,44}=6.03, P<0.001$ ), above $25 \%$ in November (ANCOVA: $\mathrm{F}=9.01, P<0.001$ ), and above $50 \%$ in both, December (ANCOVA: $\mathrm{F}_{4.44}=6.93, P<0.001$ ) and January (ANCOVA: $\mathrm{F}_{4,44}=5.81, P<0.001$ ) was significantly lower than that of control trees (figure $3 \mathrm{~A}$ ). The $\mathrm{DBH}$ of trees defoliated above $50 \%$ in October (ANCOVA: $\mathrm{F}_{4,44}=4.57$, $P<0.01$ ), November (ANCOVA: $\mathrm{F}_{4,44}=7.86, P<0.001$ ), December (ANCOVA: $F_{4,44}=9.98, P<0.001$ ) and January (ANCOVA: $\mathrm{F}_{4,44}=12.79, P<0.001$ ) was significantly lower than that of control trees (figure 3B). Trees subjected to $100 \%$ defoliation experienced the highest reduction in height and diameter growth (up to $75.6 \%$ and $87.9 \%$, respectively) as compared to control trees (figures $3 \mathrm{~A}, \mathrm{~B}$ ).

\section{DISCUSSION AND CONCLUSIONS}

Results indicated that manual defoliation affected the growth of the studied poplar and willow clones in both height and diameter, and that the magnitude of the effect depended on the intensity and timing of defoliation. Significant reductions in growth have been previously reported for high levels of artificial defoliation (75-100 \%). In poplars, Bassman et al. (1982) observed reductions in height and diameter growth of about $20 \%$ and Reichenbacker et al. (1996) recorded reductions in height and diameter growth of $12 \%$ and $9 \%$, respectively. In willows, Powers et al. (2006) reported a reduction in height growth between 5 and $20 \%$; whereas Peacock et al. (2002) observed a significant increase in height in only one of the eleven tested hybrids of Salix viminalis L. Differences in tree growth among studies may be caused by multiple factors including genetic variation among clones or environmental conditions.

Both of the studied clones showed a decrease in growth when defoliation was performed in spring, at the beginning of the growing season; while only the genus Populus was affected by summer defoliations. Defoliations of 25, 

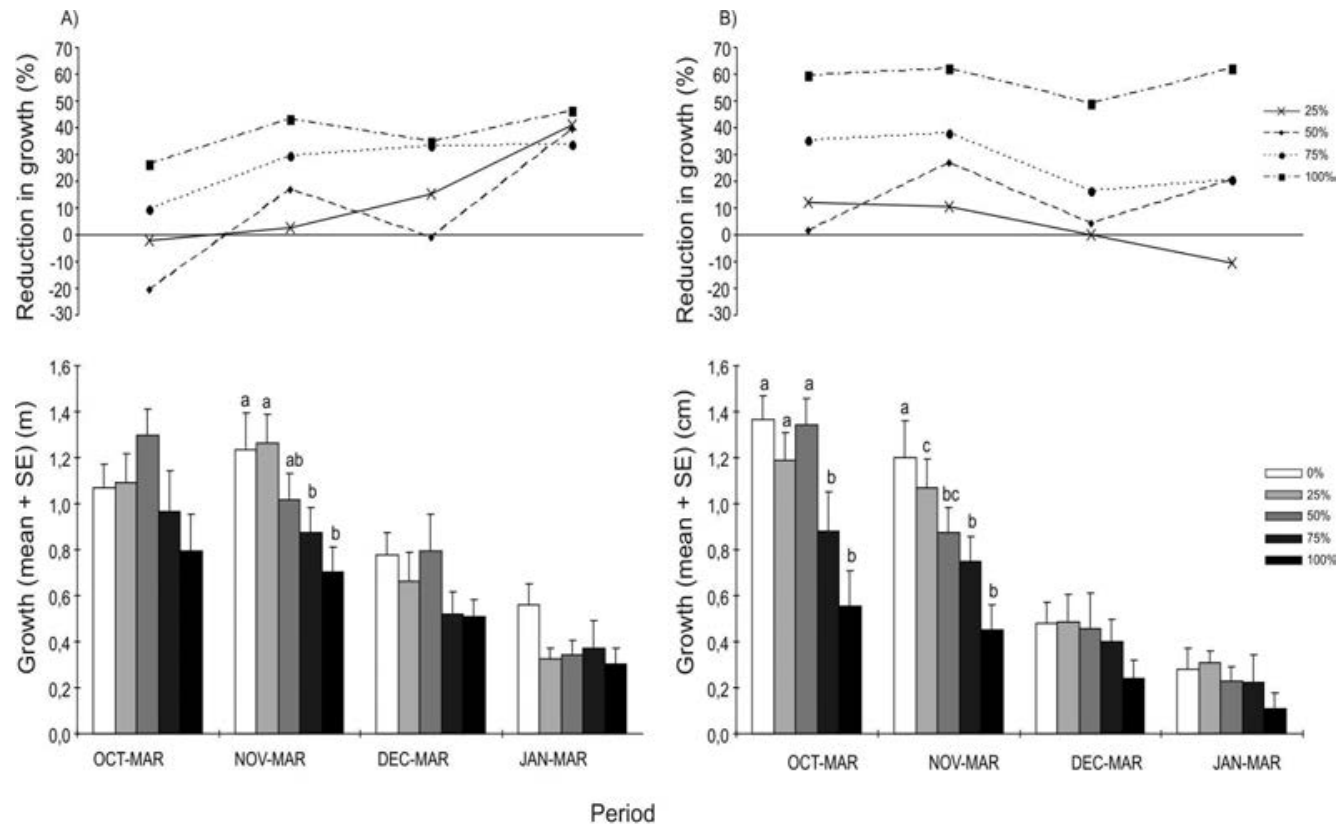

Figure 2. Growth (bars, mean + SE) and percent reduction in growth (lines) of the clone Salix babylonica x Salix alba ("A-250/33") for each defoliation level from the month of defoliation to the end of the growing season: October-March (OCT-MAR), November-March (NOV-MAR), December-March (DEC-MAR), January-March (JAN-MAR). A) Height growth. Different letters indicate significant differences $(P<0.05)$. B) Diameter growth. DBH: diameter at breast height.

Crecimiento (barras, media + EE) y porcentaje de reducción del crecimiento (líneas) del clon Salix babylonica x Salix alba ("A-250/33") para cada nivel de defoliación desde el mes de la defoliación hasta el final de la temporada de crecimiento: octubre-marzo (OCT-MAR), noviembremarzo (NOV-MAR), diciembre-marzo (DEC-MAR), enero-marzo (JAN-MAR). A) Crecimiento en altura. Letras distintas indican diferencias significativas $(P<0,05)$. B) Crecimiento en diámetro. DBH: diámetro a la altura del pecho.
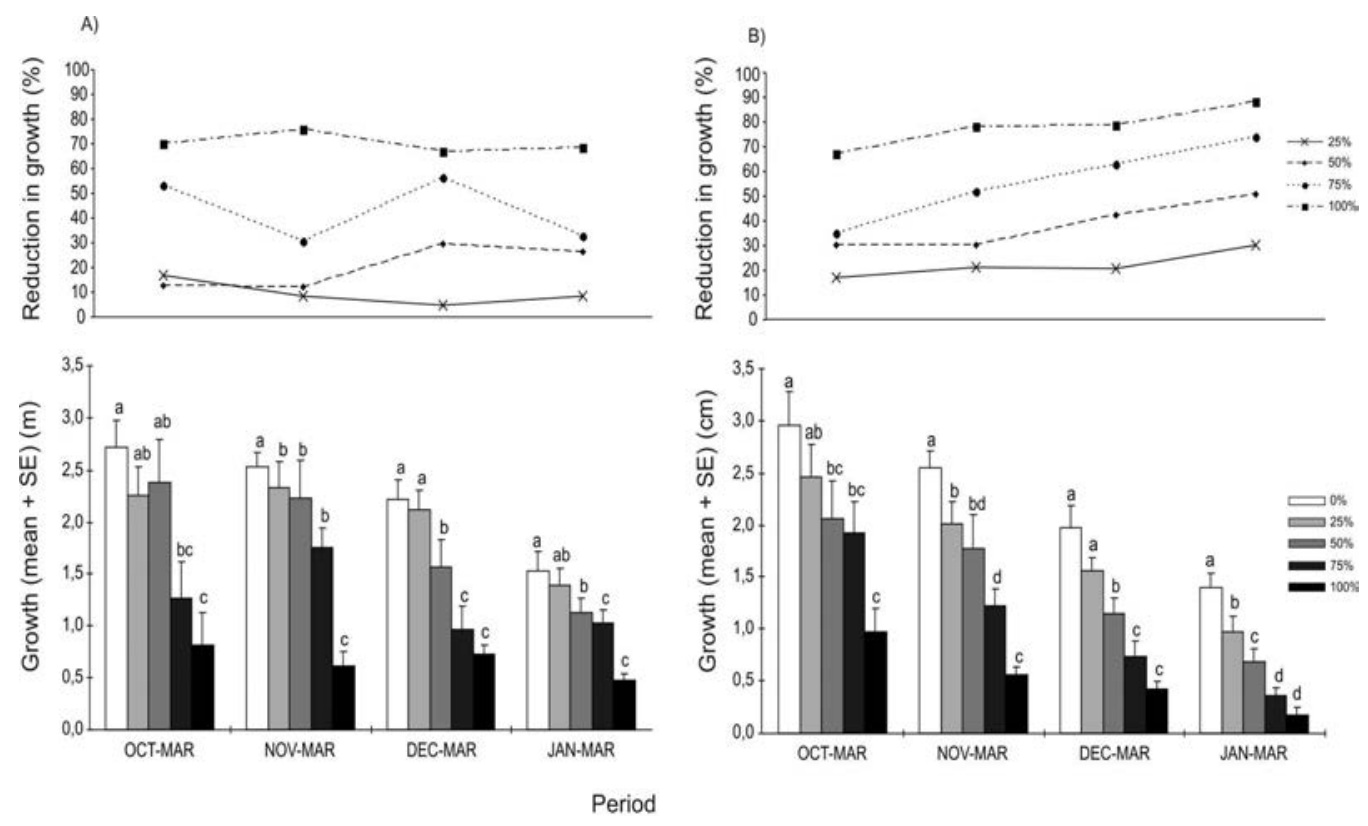

Period

Figure 3. Growth (bars, mean + SE) and percent reduction in growth (lines) of the clone Populus alba 'Villafranca' ("I-58/57") for each defoliation level from the month of defoliation to the end of the growing season: October-March (OCT-MAR), November-March (NOV-MAR), December-March (DEC-MAR), January-March (JAN-MAR). A) Height growth. Different letters indicate significant differences $(P<0.05)$. B) Diameter growth. DBH: diameter at breast height.

Crecimiento (barras, media + EE) y porcentaje de reducción del crecimiento (líneas) del clon Populus alba 'Villafranca' ("I-58/57") para cada nivel de defoliación desde el mes de la defoliación hasta el final de la temporada de crecimiento: octubre-marzo (OCT-MAR), noviembre-marzo (NOV-MAR), diciembre-marzo (DEC-MAR), enero-marzo (JAN-MAR). A) Crecimiento en altura. Letras distintas indican diferencias significativas $(P<0,05)$. B) Crecimiento en diámetro. DBH: diámetro a la altura del pecho. 
50 and $75 \%$ had a variable effect; whereas complete defoliation caused the highest reduction in growth. Although the mechanisms involved in tree growth are beyond the scope of this study, it is most likely that the results obtained are due to differential allocation of resources after defoliation. High defoliation levels at the beginning of the growing season may cause a deleterious effect on growth by the loss of young leaves with high photosynthetic activity and a decrease in carbon availability (Eyles et al. 2009); as a result, leaf production occurs at the expense of tree growth (Stevens et al. 2008). On the other hand, only willows showed increased height or diameter growth after defoliation. Trees defoliated at $50 \%$ in October were taller-and the diameter of trees defoliated at $25 \%$ in January was larger - than those of control trees. The reduction in poplar growth following defoliations during the spring and summer, and the capacity of willows to grow after moderate defoliations, may reflect a lower tolerance to defoliation of poplars than that reflected by willows. In addition to the intensity and timing of defoliation, plant characteristics (genetic, morphological, phenological and ecological) can contribute to the differentiation of closely related taxa and determine their particular response to defoliation (Trumble et al. 1993). In this sense, Salix spp. and Populus spp. have genetic and morphological distinctness (Karrenberg et al. 2002, Zalesny et al. 2005); also ecological differences emerge in studies comparing genus, species or hybrids in traits as tolerance to damage (Nordman et al. 2005, Powers et al. 2006), growth strategies adopted throughout the season (Tharakan et al. 2005), root development (McIvor et al. 2013), suitability for phytoremediation purposes (Dos Santos et al. 2007, Borghi et al. 2008) or suitability for short rotation coppice (Laureysens et al. 2005, Tharakan et al. 2005). Thus, this versatility in plant characteristics of poplars and willows would explain the differences in responses to defoliation observed in our study.

In summary, this experimental field study quantified the effect of defoliation (simulating herbivory by $N$. oligospilus) on two clones of salicaceae used for commercial plantations in the Delta of the Paraná River, through the growing season. The growth of the studied clones was affected in both height and diameter, and the magnitude of the effect depended on the intensity and timing of defoliation. However, the experiment was conducted on one-year old plantations that have rotation cycles of 10-16 years. Thus, studies over a complete harvest rotation will be required to fully assess the long-term effects of early defoliations on pulp production.

\section{ACKNOWLEDGEMENTS}

We thank J. M. García Conde and Las Carabelas (Papel Prensa S.A.) personnel for their assistance in field work. Alto Paraná S.A. and Papel Prensa S.A. provided financial and logistic support.

\section{REFERENCES}

Alderete M, G Liljesthrom, P Fidalgo. 2010. Bio-ecología y perspectivas para el manejo de la avispa sierra del sauce, Nematus oligospilus. In Villacide J, J Corley eds. Serie técnica: Manejo Integrado de Plagas Forestales. Cuadernillo $n^{0} 10$. Consulted 23 Apr. 2011. Available at http://anterior.inta. gov.ar/bariloche/info/catalog/insectos_seriemip.htm

AWC (Australian Weeds Comité, AU). 2006. Weeds of Nacional Significance - Willow resource sheet: 3 . Willow sawfly (Nematus oligospilus). Consulted 23 Apr. 2011. Available at http://www.weeds.org.au/WoNS/willows/docs/Willow_ Sawfly-Resource_Sheet3.pdf.

Ball J, A Del Lungo, J Carle. 2005. Contribution of poplars and willows to sustainable forestry and rural development. Unasylva 56: 221.

Bassman J, W Myers, D Dickman, L Wilson. 1982. Effects of simulated insect damage on early growth of nursery-grown hybrid poplars in northern Wisconsin. Canadian Journal of Forest Research 12: 1-9.

Borghi M, R Tognetti, G Monteforti, L Sebastián. 2008. Responses of two poplar species (Populus alba and Populus $x$ canadensis) to high copper concentrations. Environmental and Experimental Botany 62: 290-299.

Cedervind J. 2003. Impact of pine looper defoliation in Scots pine. Doctoral Thesis. Uppsala. Sweden. Swedish University of Agricultural Sciences. $44 \mathrm{p}$.

CIA (Comisión Internacional del Álamo, CL). 2004. Informe de la $22^{a}$ Reunión de la Comisión y de la 42ª Reunión de su Comité Ejecutivo. Consulted 20 Apr. 2011. Available at http:// www.fao.org/forestry/9499-09b7f78ead7d2ea3642c856fa13ac9378.pdf

Dimitriou I, P Aronsson. 2005. Willows for energy and phytoremediation in Sweden. Unasylva 56(221): 46-50.

Dos Santos Utmazian MN, G Wieshammer, R Vega, WW Wenzel. 2007. Hydroponic screening for metal resistance and accumulation of cadmium and zinc in twenty clones of willows and poplars. Environmental Pollution 148: 155-165.

Ede F. 2009. Can international experience help us to predict the potential impacts of willow sawfly (Nematus oligospilus Förster) on willow populations in Australia? Plant Protection Quarterly 24: 62-66.

Eyles A, E Pinkard, C Mohammed. 2009. Shifts in biomass and resource allocation patterns following defoliation in Eucalyptus globulus growing with varying water and nutrient supplies. Tree Physiology 29: 753-764.

Kandus P, RD Quintana, RF Bó. 2006. Patrones de paisaje y biodiversidad del bajo Delta del Río Paraná. Mapa de ambientes. Landscape patterns and biodiversity of the Lower Delta of the Paraná River. Landcover map. Buenos Aires, Argentina. Pablo Casamajor Ediciones. 48 p.

Kandus P, P Minotti. 2010. Distribución de terraplenes y áreas endicadas en la región del Delta del Paraná. In Blanco DE, FM Méndez eds. Endicamientos y terraplenes en el Delta del Paraná: Situación, efectos ambientales y marco jurídico. Fundación para la Conservación y el Uso Sustentable de los Humedales. Buenos Aires, Argentina. Wetlands Internacional. p. 15-32.

Karban R, IT Baldwin. 1997. Induced responses to herbivory. Chicago, USA. University of Chicago Press. 330 p.

Karrenberg S, PJ Edwards, J Kollmann 2002. The life history of 
Salicaceae living in the active zone of floodplains. Freshwater Biology 47: 733-748

Koch K, DF Waterhouse. 2000. The distribution and importance of arthropods associated with agriculture and forestry in Chile (Distribución e importancia de los artropodos asociados a la agricultura y silvicultura en Chile). ACIAR Monograph No. 68. 234 p.

Kulman HM. 1971. Effects of insect defoliation on growth and mortality of trees. Annual Review of Entomology 16: 289-324.

Laureysens I, A Pellis, J Willems, R Ceulemans. 2005. Growth and production of a short rotation coppice culture of poplar. III. Second rotation results. Biomass and Bioenergy 29: $10-21$.

MAGP (Ministerio de Agricultura, Ganadería y Pesca, AR). 2012. Dirección de Producción Forestal. Plantaciones forestales en las islas del Delta del Paraná. Consulted 30 Jul. 2013. Available at http://deltaforestal.blogspot.com. ar/2012/01/plantaciones-forestales-en-las-islas.html

Malvárez AI. 1999. El delta del río Paraná como mosaico de humedales. In Malvárez AI ed. Tópicos Sobre Humedales Subtropicales y Templados de Sudamérica. Montevideo, Uruguay. MAB-ORCYT. p. 35-53.

Marchand PP, S Masse. 2007. Short-rotation afforestation and agroforestry on Quebec private land: review of laws, regulations, policies, and programs. Quebec, Canada. Natural Resources Canada, Canadian Forest Service, Laurentian Forestry Centre, Quebec QC. Information Report LAU-X130E. 62 p.

McIvor R, S Sloan, L Rovira Pigem. 2013. Genetic and environmental influences on root development in cuttings of selected Salix and Populus clones - a greenhouse experiment. Plant and Soil. DOI 10.1007/s11104-013-1770-5.
Nordman EE, DJ Robison, LP Abrahamson, TA Volk. 2005. Relative resistance of willow and poplar biomass production clones across a continuum of herbivorous insect specialization: Univariate and multivariate approaches. Forest Ecology and Management 217: 307-318

Peacock L, S Herrick, J Harris. 2002. Interactions between the willow beetle Phratora vulgatissima and different genotypes of Salix viminalis. Agricultural and Forest Entomology 4: 71-79.

Powers SJ, L Peacock, ML Yap, P Brain. 2006. Simulated beetle defoliation on willow genotypes in mixture and monotype plantations. Annals of Applied Biology 148: 27-38.

Reichenbacker RR, RC Schultz, ER Hart. 1996. Impact of artificial defoliation of Populus growth, biomass production, and total non-structural carbohydrate concentration. Environmental Entomology 25: 632-642.

Stevens MT, EL Kruger, RL Lindroth. 2008. Variation in tolerance to herbivory is mediated by differences in biomass allocation in aspen. Functional Ecology 22: 40-47.

Tharakan PJ, TA Volk, CA Nowak, LP Abrahamson. 2005. Morphological traits of 30 willow clones and their relationship to biomass production. Canadian Journal of Forest Research 35: 421-431.

Trumble JT, DM Kolodny-Hirsch, IP Ting. 1993. Plant compensation for arthropod herbivory. Annual Review of Entomology 38: 93-119.

Zalesny RS Jr, R. B. Hall, EO Bauer, DE Riemenschneider. 2005. Soil temperature and precipitation affect the rooting ability of dormant hardwood cuttings of Populus. Silvae Genetica 54: 47-58.

Zar J. 1984. Biostatistical Analysis. Englewood Cliffs, New Jersey, USA. Prentice-Hall. 719 p. 